\title{
ISLAM DI SPANYOL: Kemunduran dan Kehancuran
}

\author{
Firdaus \\ Universitas Islam Negeri Sultan Syarif Kasim Riau Jalan H.R. Soebrantas Km. 15 Panam Pekanbaru \\ e-mail: daus@yahoo.com
}

Abstract

Islam in Spain had an important role in many areas, especially science and culture. The history reveals that Islam reached its peak in the era of Abd al Rahman III (912-961 AD) when Cordova became the center of Islamic civilization in Western World, and one of the centers of world civilization (Hitti, no year: 165). After reaching its peak, Islam domination declined due to the change of political structure. Decline and destruction of Islam in Spain were caused by some factors, both internal and external, that is, the attack from the Christians who directly destroyed Islam, but the most dominant factor was the internal factor of Islam itself.

Key words: Islam, peak, decline, destruction

\section{Pendahuluan}

Islam sebagai fenomena sejarah mengalami masa-masa pertumbuhan, kemajuan dan juga kemunduran. Keberhasilan perluasan wilayah Islam pada masa pemerintahan Dinasti Umayah ditindaklanjuti kemajuan peradaban Islam oleh pemerintahan Abbasiyah di Bagdad dan oleh pemerintahan Umayah 
di Cordova (Spanyol), menjadikan Islam sebagai adikuasa dunia. Kemajuan tersebut terdapat ketika umat Islam berada dalam kesatuan politik di bawah sistem khilafah. Islam di Spanyol sejak pertama kali berkembang sampai berakhirnya kekuasaannya di sana telah memainkan peranan yang sangat besar. Masa ini berlangsung selama delapan abad, mulai penaklukan dan penundukan yang dipimpin oleh Tariq ibnu Ziyad pada tahun $711 \mathrm{M}$ sampai jatuhnya kota Granada dari Dinasti Bani Ahmar ke tangan pemerintahan Kristen pada tahun 1492 M (Syalabi, 1979: 76).

Pada tahap awal sejak menjadi kekuasaan Islam, Spanyol diperintah oleh wali-wali yang diangkat oleh pemerintah Bani Umayyah di Damaskus. Pada masa ini kondisi sosial politik masih diwarnai perselisihan yang disebabkan karena komplesitas etnis dan golongan. Juga timbulnya gangguan dari sisa-sisa musuh Islam di Spanyol yang bertempat tinggal di wilayah pedalaman. Masa ini berlangsung sampai datangnya salah seorang keturunan Muawiyah yang berhasil menyelamatkan diri kekejaman al Saffah yaitu Abdur Rahman yang bergelar 'al Dakhil' pada tahun 138 H/755 M. Selanjutnya ia mendirikan Dinasti Umayah yang tidak lagi terikat oleh pemerintahan pusat (al Abbadi, 1964: 65).

Selama berkuasa dalam rentang waktu yang panjang, Islam di Spanyol telah mengisi lembaran sejarah Islam. Ia tumbuh, berkembang dan mencapai kemajuan dalam berbagai bidang terutama ilmu pengetahuan dan kebudayaan. Dari segi ilmu pengetahuan kemajuan Islam di Spanyol dapat dibuktikan dengan berdirinya berbagai lembaga pendidikan, sehingga tidak ada kota, betapapun kecilnya yang tidak memiliki sekolah. Setiap kota utama mempunyai perguruan tinggi sendiri (Mahmudunnasir, tt: 307-308). Universitas Cordova yang didirikan Abd al Rahman III dan Universitas Granada yang didirikan Abu Yusuf al Hajjaj menjadi pusat perkembaagan ilmu pengetahuan. Kedua lembaga pendidikan ini telah memberikan sumbangan yang penting terhadap perkembangan ilmu pengetahuan dan sekaligus memunculkan ilmuwanilmuwan yang terkenal bagi perkembangan Islam di dataran Eropa (Tim penulis IAIN Syahid, 1992: 121).

Sedang dalam bidang kebudayaan kemajuan Islam di Spanyol dibuktikan 
dengan berdirinya gedung, kota, istana, mesjid dan taman. Di antara bangunan yang megah adalah mesjid Cordova, kota al Zahrah, istana Ja'fariyah, tembok Tokdo, mesjid Sevilla dan istana al Hamra di Granada (Yatim, 1994: 104).

Dalam catatan sejarah, kemajuan Islam mencapai puncaknya pada masa pemerintahan Abd al Rahman III (912-961 M) dimana Cordova menjadi pusat peradaban Islam di Barat, sekaligus menjadi salah satu pusat peradaban dunia (Hitti, 1970: 165). Setelah mencapai puncak kejayaan, kekuasaan Islam di Spanyol mengalami perubahan struktur politik yang membawa kepada kemunduran. Hal ini mulai tampak setelah wafatnya kalifah al Hakam II. Kemunduran tersebut membawa kepada hancurannya Islam di Spanyol, bahkan sampai kepada tragedi pembantaian dan pengusiran secara paksa umat Islam oleh penguasa Kristen (Qutub, 1991: 51-55).

Kemunduran dan kehancuran Islam di Spanyol disebabkan oleh beberapa faktor baik faktor dazi dalam (intern) maupun dan luar (ekstern). Dan inilah pembahasan pokok yang akan diangkat dalam makalah ini.

\section{Faktor-Faktor Intern Kemunduran dan Kehancuran}

Islam di Spanyol mengalami kemunduran disebabkan oleh beberapa faktor dari dalam, yaitu:

\section{Perpecahan dan perebutan kekuasaan}

Pada tahap awal semenjak menjadi wilayah Islam, Spanyol masih diwarnai perpecahan dan perebutan kekuasaan sehingga stabilitas politik negeri Spanyol belum tercapai secara sempurna. Hal ini disebabkan perselisihan di antara elite penguasa akibat perbedaan etnis dan golongan. Juga terdapat perbedaan pandangan antara khalifah di Damaskus dan gubernur Afrika Utara yang berpusat di Kairawan. Masing-masing mengakui bahwa merekalah yang paling berhak menguasai daerah Spanyol. Oleh karena itu fase awal ini telah terjadi dua puluh kali pergantian wali (gubernur) Spanyol dalam jangka waktu yang amat singkat. Jadi tidak ada gubernur yang mampu mempertahankan kekuasaannya untuk jangka waktu yang agak lama (Yatim, 1994: 94).

Ketika Abdul al Rahman I (al Dakhil) menduduki jabatan Amir, perpecahan, kerusuhan dan pemberontakan terus berlangsung. Selama 
beberapa tahun kekuasaannya diperebutkan oleh orang Barbar, Yamaniyah dan Tahiriyah (Mahmudunnasir, tt: 285). Namum perpecahan tersebut dapat diatasi. Demikian halnya pada masa pemelintahan Hisyam, perpecahan terjadi antara saudaranya sendiri. Abdullah dan Sulaiman mengadakan pemberontakan tapi dapat digagalkan oleh Hisyam (Mahmudunnasir, tt.: 228). Pada masa pemerintahan Hakam terjadi kekisruhan akibat ketidakramahannya terhadap fuqaha, ia tidak menghendaki campur tangan fuqaha dalam urusan negara. Akibatnya timbul gerakan fuqaha yang ingin menggulingkan kekuasaan Hakam dan ini melatari terjadinya pemberontakan di Cordova (Ali, 1996: 304).

Perpecahan dan perebutan kekuasaan semakin parah setelah meninggalnya Hakam II, yang memerintah selama 14 tahun (961-976 M). Ia digantikan oleh putraya Hisyam II yang masih berusia relatif muda yaitu sebelas tahun. Akibatnya ia tidak dapat melaksanakan sistem dan aturan pemelintahan sebagaimana mestinya. Terjadilah silang pendapat di antara pejabat negara yang terbagi ke dalam dua kubu. Kalangan militer berpendapat bahwa untuk melaksanakan hal-hal yang berkaitan dengan kekhalifahan harus diserahkan kepada pamannya al Mughirah Ibnu Abd al Rahman. Sedangkan pihak sipil berpendapat bahwa pemerintahan tetap di tangan Hisyam II, walaupun ia masih anak-anak. Terjadinya perebutan kekuasaan di kalangan pejabat negara mengakibatkan terbunuhnya Mughirah Ibnu Abd al Rahman. Tragedi pembunuhan itu dilakukan oleh kalangan sipil yang dipimpin oleh Ja'far al Mushafi, seorang menteri yang dipercayakan untuk menjalankan urusan pemerintahan ketika Hakam II sakit (al Abbadi, 1964: 130).

Pada saat-saat terakhir kekuasaan Islam di Spanyol, perebutan kekuasaan terjadi lagi. Wilayah kekuasaan Islam pada saat itu tinggal Granada di bawah pemerintahan Dinasti Bani Ahmar (1232-1492 M). Dinasti ini terkenal dengan sebutan al Hambura yang pernah jaya dan dikagumi, terutama pada masa pemerintahan Abd al Rahman al Nasir. Namun akhirnya melemah karena terjadinya perebutan kekuasaan dan dua putra penguasa Abu Abdullah Muhamammad merasa tidak senang kepada ayahnya, karena menunjuk anaknya yang lain sebagai penggantinya menjadi raja. Dia memberontak dan berusaha merampas kekuasaan. Dalam pemberontakan itu, ayahnya 
terbunuh dan digantikan oleh Muhammad bin Sa'ad. Akibatnya kekuasaan Islam terpecah dan melemah (Yatim, 1994: 99). Inilah perebutan kekuasaan yang terakhir dalam kekuasaan Islam Spanyol dan kesempatan emas ini dipergunakan oleh orang Kristen untuk mengusir orang Islam dari Spanyol untuk selama-lamanya.

\section{Pribadi dan Kepemimpinan Khalifah}

Salah satu penyebab kemunduran Islam di Spanyol adalah faktor pribadi dan kepemimpinan khalifah. Hal ini tampak ketika Hisyam II naik tahta menggantikan ayahnya Hakam II. Ia termasuk khalifah yang lemah, tidak memiliki kemampuan dan kecakapan untuk mengurus negara, karena menduduki kursi kekhalifahan dalam usia yang relatif muda. Ia tidak mampu membaca dan mengamati gerakan Kristen yang mulai tumbuh dan mengancam kekuasaannya (al Abbadi, 1964: 131).

Kekuasaannya dapat bertahan lama dalam pemerintahan karena keberadaan Muhammad Ibnu Abi 'Amir yang menjabat sebagai pelaksana kebijaksanaan politik dan kekuasaan pemerintahan yang cukup disegani kawan maupun lawan. Muhammad Ibnu Abi 'Amir adalah tokoh militer pada masa pemerintahan khalifah Hakam II dan dengan keperkasaannya ia berhasil memperkecil wilayah kerajaan Kristen yang terletak di sebelah utara Spanyol. Pada masa pemerintahan Hisyam II, ia menjadi perdana menteri dan merebut Maroko dari kekuasaan Fatimiyah (984 M) (Hassan, 1989: 214).

Dia menyebut dirinya dengan Malik al Mansur Billah (yang dimenangkan oleh Allah), biasa disebut al Manzor di Eropa. Sementara itu khalifah Hisyam II yang sudah dewasa hanya merupakan sebuah boneka, penguasa sebenarnya adalah al Mansur. Hak khalifah saat itu tinggal namanya yang selalu disebutkan di dalam doa dari mimbar-mimbar khutbah pada setiap hari Jum'at, hari raya, dan pembubuhan cap setiap keputusan yang dikeluarkan dan diumumkan oleh Muhammad Ibnu Abi Amir (Sou'yb, 1977: 145).

Setelah al Mansur meninggal, ia digantikan oleh putranya Abd al Malik Ibnu Muhammad dengan gelar al Muzaffar. Dia seperti bapaknya negarawan yang cakap dan ahli strategi, sehingga pada masa menduduki jabatan keadaan pemerintahan masih tetap berjalan dengan baik (al Abbadi, 1964: 138). 
Setelah Abd al Malik meninggal pada tahun 1009 M ia digantikan oleh saudaranya Abd al Rahman Ibnu Muhammad. Pada masa pemerintahannya, situasi politik di Cordova mulai memburuk, kekacauan dan pemberontakan semakin bertambah (Mahmudunnasir, tt.: 311).

Abd al Rahman tidak sama dengan bapak dan saudaranya terdahulu. Ia tidak memiliki kecakapan dan keahlian yang diperlukan bagi jabatannya, Ia haus kebesaran dan kekuasaan. Ia sedemikian cepat memamerkan lambanglambang kebesaran khilafah untuk dirinya. Dan menuntut khalifah Hisyam II untuk menunjuk dan mengumumkannya sebagai khalifah sepeninggalnya kelak. Tuntutannya diperkenankan begitu saja oleh khalifah Hisyam II. Akibatnya kalangan istana menjadi marah yang membawa terjadinya kudeta dan khalifah Hisyam II ditahan. Tetapi kemudian dapat meloloskan diri dan lari ke kota Malaga (Sou'yb, 1977: 159).

Ketidakmampuan penguasa dan khalifah memelihara stabilitas politik dan pemerintahahn menjadikan para penguasa di tingkat wilayah seperti propinsi, mulai tidak percaya pada kekuasaan khalifah dan mengambil sikap melepaskan diri dari kekhalifahan yang berpusat di Cordova, akibatnya berdirilah dinasti-dinasti kecil yang dikenal dengan Muluk al Tawaif atau reyes de taifas (Hitti, 1974: 537).

\section{Munculnya Dinasti-Dinasti Kecil}

Disintegrasi kekuatan Islam di Spanyol dengan munculnya dinasti-dinasti kecil merupakan salah satu penyebab kemunduran dan kehancuran Islam di Spanyol. Meskipun demikian pada masa ini terjadi pula kecemerlangan kultural. Sejumlah dinasti lokal berkuasa di berbagai bagian Spanyol. Sebagian di antaranya hanyalah negara kota, sebagaian lagi sepeiti Afthasia di barat daya, menguasai wilayah yang amat luas. Dinasti-dinasti ini dari berbagai ras, yang mencerminkan heterogenitas kelas-kelas militer di bawah Umayah dan ketegangan etnis dan persaingan di kalangan kelompok-kelompok ini (Bosworth, 1993: 35). Dinasti-dinasti kecil yang berkuasa di berbagai bagian di Spanyol ini mencapai jumlah dua puluh buah (Hitti, 1974: 121). Data lain menyebutkan berkisar tiga puluh, atau dua puluh tiga (Watt, 1990: 218).

Antara dinasti-dinasti tersebut sering terjadi konflik bersenjata yang 
tak segera padam. Mereka bertahan mati-matian untuk mempertahankan wilayahnya, bahkan tidak jarang mereka bersekongkol dan meminta bantuan kepada orang Kristen untuk menyerang sesama Muslim (Syalabi, 1979: 72). Sebagai contoh, Umar al Mutawakkil, Raja Dinasti Afthasia terakhir, siap menyerahkan sebahagian besar wilayah yang dikuasainya kepada Alfonso IV dari Leon dan Castile sebagai imbalan atas bantuan Alfonso kepada Umar ketika ia menghadapi al Murawiyah (Bosworth, 1993: 36). Terjadinya persaingan antara dinasti-dinasti kecil merupakan kesempatan emas bagi penguasa Kristen melakukan politik adu domba, akibatnya mereka saling berperang. Kemudian penguasa Kristen memberikan bantuan kepada pihak yang memerlukan bantuan. Permintaan bantuan dari dinasti Islam kepada penguasa Kristen merupakan suatu kesalahan besar dan fatal, karena kelemahan Islam dapat diketahui secara langsung, sehingga memudahkan penguasa Kristen mencaplok daerah kekuasaan Islam satu persatu, sampai akhimya Islam hilang dari daratan Spanyol.

\section{Kesulitan Ekonomi}

Keadaan ekonomi juga dapat menentukan maju mundurnya suatu negara. Di paruh kedua masa Islam di Spanyol pembangunan kota dan pengembangan ilmu pengetahuan sangat gencar dan serius, sehingga lalai membina perekonomian. Akibatnya timbul kesulitan ekonomi yang sangat mempengaruhi kondisi politik dan militer (Yatim, 1994: 108). Di samping itu pasukan muslim yang menyita harta milik orang-orang kaya di Spanyol dan kekayaan para raja dan pejabat negara, tidak mengembangkan kekayaan tersebut secara baik, akibatnya pendapatan negara merosot. Kemudian lebih parah lagi setelah munculnya khalifah yang lemah yang tidak lagi memperhatikan kemaslahatan rakyatnya, tetapi bergelimang dalam kemewahan dan hanya ingin bersenang-senang semata. Akhirnya penghasilan negara terkuras untuk kepentingan khalifah. Belum lagi biaya yang dikeluarkan untuk membiayai peperangan untuk menumpas kerusuhan-kerusuhan. 


\section{Faktor-Faktor Ekstern Kemunduran dan Kehancuran}

Selain faktor-faktor intern yang telah disebutkan di atas, terdapat pula faktor ekstern yang menyebabkan kemunduran dan kehancuran Islam di Spanyol, yakni:

\section{Konflik Islam-Kristen}

Kehadiran bangsa Arab Islam di Spanyol secara tidak langsung melahirkan kesadaran kebangsaan orang-orang Kristen Spanyol. Sehingga kehidupan negara Muslim Spanyol tidak berhenti dari pertentangan antara pihak Muslim dengan pihak Kristen. Semenjak abad XI kekuatan Kristen mulai bertambah kuat, sementara umat Islam mulai mengalami kemunduran. Ini. akibat kebijaksanaan para khalifah ketika menguasai Spanyol tidak melakukan Islamisasi secara sempurna, tetapi mereka membiarkan orang-orang Kristen mempertahankan hukum dan tradisi mereka asal tetap membayar upeti dan tidak melakukan perlawanan bersenjata (Yatim, 1994: 107).

Wilayah kekuasaan Islam di Spanyol berbatasan dengan kerajan-kerajaan Kristen di Utara yang selalu mencari kesempatan untuk menyerang Islam. Apalagi ketika Islam Spanyol pecah ke dalam beberapa dinasti-dinasti kecil atau Muluk al Tawdif, peta kekuatan Islam mulai menurun. Sebaliknya raja-raja Kristen di Utara mulai bersatu dan mengadakan penyerangan-penyerangan, akhirnya satu demi satu dinasti-dinasti Islam dapat ditaklukkan. Serbuan yang dilakukan oleh raja Alfonso VI berhasil merebut Toledo dari dinasti Zunniyah pada tahun 1085 M (Al Abbadi, 1964: 156). Dalam kondisi yang demikian, umat Islam tidak mampu membendung serangan-serangan dari pihak Kristen yang semakin gencar. Akhirnya satu persatu wilayah Islam dikuasai oleh Kristen. Cordova jatuh pada tahun $1238 \mathrm{M}$, menyusul Seville tahun 1248 dan wilayah-wilayah lain kecuali Granada (Syalabi, 1979: 76).

Di bawah kekuasaan Bani Ahmar, Granada dapat bertahan selama dua abad lebih. Tapi pada tahun 1469 M, kerajaan Aragon dan Castilia bersatu menyerang Islam di Granada, sehingga pada tanggal 1 Januari 1492, Granada dikepung dan ditaklukkan oleh penguasa Kristen (Hitti, 1974: 555). Dengan jatuhnya Granada ke tangan Kristen, maka Islam sebagai kekuatan politik dan agama hilang dari daratan Spanyol. Dan pada tahun 1609, raja Philip III menguasai secara paksa 
orang-orang Islami di Spanyol dengan dua pilihan, masuk Kristen atau keluar dari Spanyol (Nasution, 1985: 82).

\section{Faktor Geografis}

Faktor Geografis juga menentukan hilangnya Islam di Spanyol. Karena Spanyol merupakan daerah terpencil dari dunia Islam yang lain, sehingga ia selalu berjuang sendirian, tanpa mendapatkan bantuan kecuali dari Afrika Utara. Dengan demikian tidak ada kekuatan alternatif yang mampu membendung kebangkitan Kristen di Spanyol (Yatim, 1994: 108). Selain itu faktor iklim juga mempengaruhi, sehingga orang-orang Arab sebagai pendatang tidak tahan mendiami daerah Spanyol yang iklimya tidak cocok dengan mereka (Watt, 1990: 43).

\section{Simpulan}

Kemunduran dan kehancuran Islam di Spanyol tidak terlepas dari faktor intern dan faktor ekstern yaitu berupa serangan dari pihak Kristen yang secara langsung menghancurkan Islam, namun yang paling dominan adalah faktor dari Islam itu sendiri.

\section{Daftar Pustaka}

Al Abbadi, Abd al Hamid. 1964. al Mujmal fi Tarikh at Andalus. Kairo: Dar al Qalam.

Ali, K. 1996. Sejarah Islam Tarih Pramodern. Jakarta: PT. Raja Grafindo Persada.

Bosworth, G.E. 1993. The Islamic Dinasties. Terjemahan oleh Ilyas Hasan. Bandung: Mizan.

Hassan, Ibrahim Hassan. 1989. Sejarah dan Kebudayaan Islam. Terjemahan oleh Djahdan Humam. Yogyakarta: Kota Kembang.

Hitti, Phillip K. 1970. Dunia Arab Sejarah Ringkas, terjemahan oleh Usuluddin Hutagalung \& O.P.D. Sihombing. Bandung: Sumur. 
Hitti, Phillip K, 1974. History of the Arabs. London: The Macmillan Press.

Mahmudunnasif, Syed. Tt. Islam Konsepsi dan Sejarahnya. Terjemahan oleh Adang Afandi. Bandung: Remaja Rosdakarya.

Nasution, Harun. 1985. Islam Ditinjau dari Berbagai Aspeknya. Jilid I. Jakarta: UI Press.

Qutub, Muhammad Abi. 1991. Fakta Pembantaian Muslimin di Andalusia. Terjemahan oleh Mustafa Mahdani. Jakarta: Pustaka Mantiq.

Sou'yb, Yoesoef. 1977. Sejarah Daulah Umayyah II di Cordova. Jakarta: Bulan Bintang.

Syalabi, Ahmad. 1979. Mausu'at al Tarikh al Islamiy wa al Haddrat al Islamiyat. Jilid IV. Mesir: Maktabat al Nahdah al Misriyat.

Tim Penulis IAIN Syahid. 1992. Ensiklopedi Islam Indonesia. Jakarta: Djambatan.

Watt, W. Montgomery. 1990. Kejayaan Islam, Kajian Kritis dari Tokoh-Tokoh Orientalis. Yogyakarta: Tiara Wacana.

Yatim, Badri. 1994. Sejarah Peradaban Islam. Jakarta: Raja Grafindo Persada. 